\title{
Reactivity to being photographed: An invasion of personal space
}

\author{
MICHAEL N. GUILE, NEIL R. SHAPIRO, and ROBERT BOICE \\ State University of New York, Albany, New York 12222
}

\begin{abstract}
Although much anecdotal evidence exists about human subjects' reactivity to being photographed, this behavior has been little examined. The present study was a field experiment in which unaccompanied members of an American university community had their photographs taken by a photographer unfamiliar to them. The results indicate that subjects react to having their photographs taken as an invasion of personal space, frequently responding with displays of submission.
\end{abstract}

It is a common experience of photographers (both amateur and professional) to find that American subjects have strong reactions to having their photographs taken. Avoidance responses, as well as displays of amusement, are typical. Many guides to photography offer helpful hints to circumvent the reactivity problem. It is also regarded as an obstacle by investigators of nonverbal communication who utilize film (Hass, 1970; Kendon, 1979; Knapp, 1978). It would seem that being directly confronted with a camera lens is a potent indication of gaze-directed behavior (Argyle, 1969; Kendon, 1967) that can be responded to as an invasion of personal space, much as staring is (Ellsworth, Carlsmith, \& Henson, 1972). There is a sizable spatial invasion literature (Sundstrom \& Altman, 1976), but, despite its commonplace occurrence, the response to being photographed per se has not received attention. The following study was a field experiment designed to examine this reaction, in which subjects traversing a flight of stairs had their pictures taken by a photographer unfamiliar to them.

\section{METHOD}

\section{Subjects}

Twenty-one male and female unaccompanied members of the State University of New York at Albany community were randomly assigned to the experimental $(n=10)$ and control $(n=11)$ groups. Most subjects appeared to be college-aged individuals.

\section{Materials and Procedure}

The site of the experiment was a stairwell leading up to the academic podium of the State University of New York at Albany campus. The stairwell was $4.08 \mathrm{~m}$ deep and $3 \mathrm{~m}$ wide. All steps were $31 \mathrm{~cm}$ across, with the exception of a landing $1.8 \mathrm{~m}$ across after the 12 th step. There were another 12 steps to the top after the landing. Steps were $17 \mathrm{~cm}$ high. Handrails $7.5 \mathrm{~cm}$ wide and $1 \mathrm{~m}$ high ran the length of the edges of the stairs and up the

Address reprint requests to Michael Guile, Department of Psychology, State University of New York at Albany, 1400 Washington Avenue, Albany, New York 12222. The authors thank Farrell Malkis and Paul Rosenfeld for their comments. center of the stairs, but not across the landing. Four people could comfortably walk abreast up or down the stairs. The study was conducted during daylight hours in the late fall; ambient temperature ranged from $10^{\circ} \mathrm{C}$ to $12^{\circ} \mathrm{C}$.

The experimenter positioned himself at the top of the steps, with a single-lens reflex camera with a 50-mm lens hung on a strap around his neck. Subjects were persons walking alone, about to start up the steps. In the experimental condition, the experimenter positioned himself diagonally across from the subjects, raised the camera to eye level, and began tracking and focusing on the subjects as soon as they started up the first set of steps. The experimenter took the subjects' photographs as soon as they reached the first step after the landing, but he continued to track the subjects through the lens of the camera until they reached the top of the stairs-typically passing within $30 \mathrm{~cm}$ of the experimenter. In the control condition, the experimenter left the camera on the strap around his neck, placed his arms at his sides, and simply gazed at the eyes of the subjects until they passed him at the top of the stairs.

Each subjectexperimenter interaction was recorded by an observer unobtrusively operating a Polavision movie camera with a zoom lens from a third-floor window above and to the rear of the experimenter, $25.5 \mathrm{~m}$ away $(9 \mathrm{~m}$ above the ground). The film cassettes were later scored (in a manner similar to the procedure of Veno, 1976, p. 97) first as to whether or not each subject showed a visible response and second as to the quality of the reaction, if a response occurred. Displays were classified as either submissive (running from or smiling at the experimenter) or aggressive.

\section{RESULTS AND DISCUSSION}

Six out of 10 subjects in the camera condition $(60 \%)$ reacted to the experimenter, but only 1 out of 11 subjects in the control condition (9\%) reacted. This difference was significant (Fisher exact probability test, $\mathrm{p}<.02$ ). None of the subjects who reacted in either condition displayed any aggressive responses. All responses to the experimenter were submissive, involving either smiling at the experimenter or running from the experimenter (flight). The one subject in the control group who reacted smiled at the experimenter. In the experimental condition, four reacting subjects $(67 \%)$ smiled and two (33\%) displayed flight.

The reactivity of American university subjects to having their photographs taken was clearly demon- 
strated. The camera was disrupting and was regarded as an invasion of personal space that was responded to here with submission. Felipe and Sommer (1966) have shown the response to violation of personal space to range from flight to agonistic behavior. Flight was displayed in the present experiment, and although agonistic responses were not, there is ample anecdotal evidence to suggest that the taking of a photograph can lead to such reactions (McGinniss, 1969, p. 96). What is now needed in the study of the invasion of personal space by photographers is a systematic manipulation of variables such as sex of experimenter and sex of subject, attractiveness and status of experimenter, locale of experiment, and so on.

\section{REFERENCES}

Argyle, M. Social interaction. New York: Aldine-Atherton, 1969. Ellsworth, P. C., Carlsmith, J. M., \& Henson, A. The stare as a stimulus to flight in human subjects. Journal of Personality and Social Psychology, 1972, 21, 302-311.
Felipe, N. J., \& Sommer, R. Invasions of personal space. Social Problems, 1966, 14, 206-214.

Hass, H. [The human animal] (J. M. Brownjohn, trans.). New York: G. P. Putnam's Sons, 1970.

Kendon, A. Some functions of gaze-direction in social interaction. Acta Psychologica, 1967, 26, 22-63.

Kendon, A. Some theoretical and methodological aspects of the use of film in the study of social interaction. In G. P. Ginsberg (Ed.), Emerging strategies in social psychological research. New York: Wiley, 1979.

KNAPP, M. L. Nonverbal communication in human action (2nd ed.). New York: Holt, Rinehart, \& Winston, 1978.

McGinniss, J. The selling of the president 1968. New York: Trident Press, 1969.

Sundstrom, E., \& Altman, I. Interpersonal relationships and personal space: Research review and theoretical model. Human Ecology, 1976, 4, 47-67.

Veno, A. E. Response to approach: A preliminary process oriented study of human spacing. Social Science Information, 1976, 15, 93-115. 